\title{
A visual story of inclusion
}

\author{
Invisible No More: A Photographic \\ Chronicle of the Lives of People with \\ Intellectual Disabilities \\ Vincenzo Pietropaolo \\ Rutgers University Press; 2010.
}

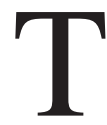

his collection of photographs of people with intellectual disabilities from across North America by noted Toronto documentary photographer, Vincenzo Pietropaolo, is a book with a consistent theme and clear raison d'être. The photos, and the short texts that accompany them (written by the photographer himself), are a testament to Pietropaolo's ability to penetrate into these intimate worlds without any sense of aggression or intrusion.

Unlike, for example, the famous photos of the American photographer, Diane Arbus, who often photographed her subjects as studies in "difference," Pietropaolo's theme is one of "inclusion." The subjects of Arbus photos often stood alone, separate from the world, almost as icons of divergence from the norm. Even though Arbus was

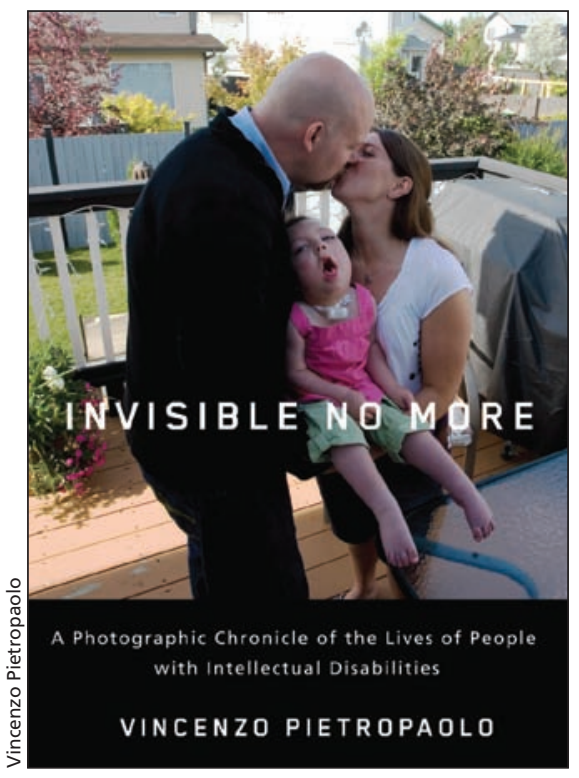

people are not aberrant but part of the human continuum. They are deceptively simple photos, but taken together they form a symphony of inclusion, of lives in context.

For example, in a small town in Ohio, the photographer joins a family for dinner. Van, who has Down syndrome, is proud to pour the ice water in

\section{Pietropaolo has an ability to penetrate into these intimate worlds without any sense of aggression or intrusion.}

widely criticized for her take on her art, she actually felt her photos were lyric and tender and called her subjects "aristocrats."

The subjects in Invisible No More are almost always within context, usually surrounded by and interacting with family, caregivers and friends. For example, the cover photo depicts a man and wife kissing while holding their severely disabled infant. The point is to show that the lives of these everyone's glass. Pietropaolo notes, "As dinner comes to an end ... it occurs to me that Van's disability had long ago been absorbed by the rest of his family."

Because the photos are seldom connected to the text on the same page, the viewer/reader is sometimes not quite sure which person in the photo is the disabled one. While this can lead to some confusion, it effectively augments the theme that these people are not different or separate from us they are us.

The photographer is quite aware of his possible intrusion, telling us of one photo he refused to take. A father feeds his 33-year-old daughter who has multiple and severe disabilities. She is blind, has no functional use of her hands, no ability to communicate and cannot hold up her head. Pietropaolo writes, "The scene between Joseph and Alexis is so tender and intimate that I didn't feel I had the right to intervene with the sound of the camera." Again and again, the photographer questions what his intruding presence means. In some way, this thread of doubt imbues the photos with a sensitivity that is profoundly moving.

Pietropaolo lets these people - both the disabled and their families - touch the reader's heart. The older siblings of a Down syndrome infant notes, " ... he forced us to grow up really fast." A mother admits that it took her eight years to truly accept her disabled daughter but that her husband "loved her from day one."

Another theme that runs through the collection is the importance of work in disabled peoples' lives. Anyone who has the ability wants to partake in the simple human dignity that arises from work, from having a job to do, from contributing to society and earning a living. We see a number of disabled people working: cutting and packing lobster, building houses, picking onions, operating an industrial dishwasher. Generally they love their jobs and are good at them. One employer noted, "He hasn't missed a day in seven years." How many of us can claim that kind of record?

The importance of music in many lives is also documented. In Powell River, British Columbia, John, a local musician comes into a group home to 
play music for Andre, who is severely disabled, is strapped into a wheelchair and cannot speak. John sings, plays recorder, flute, guitar, piano. With guttural sounds, Andre sings along. John says Andre "is a sound surfer. He rides the sound waves."

In a simple statement that says everything about the disabled and those who would assist them and accept them for who they are, John adds, "Sad music is also joyful, I think."

\section{Mark Frutkin \\ Poet and author \\ Ottawa, Ont.}

The following images and extended captions are reprinted with permission from Invisible No More: A Photographic Chronicle of the Lives of People with
Intellectual Disabilities (Rutgers

University Press, 2010). Pietropaolo, a documentary photographer, has published seven books, including Harvest Pilgrims: Mexican and Caribbean Migrant Farm Workers in Canada.

His work was featured recently in the Italian Pavilion of the 2011 Venice Biennale (www.youtube.com/watch?v=U0rtjz-cii0).

CMAJ 2012. DOI:10.1503/cmaj.110934

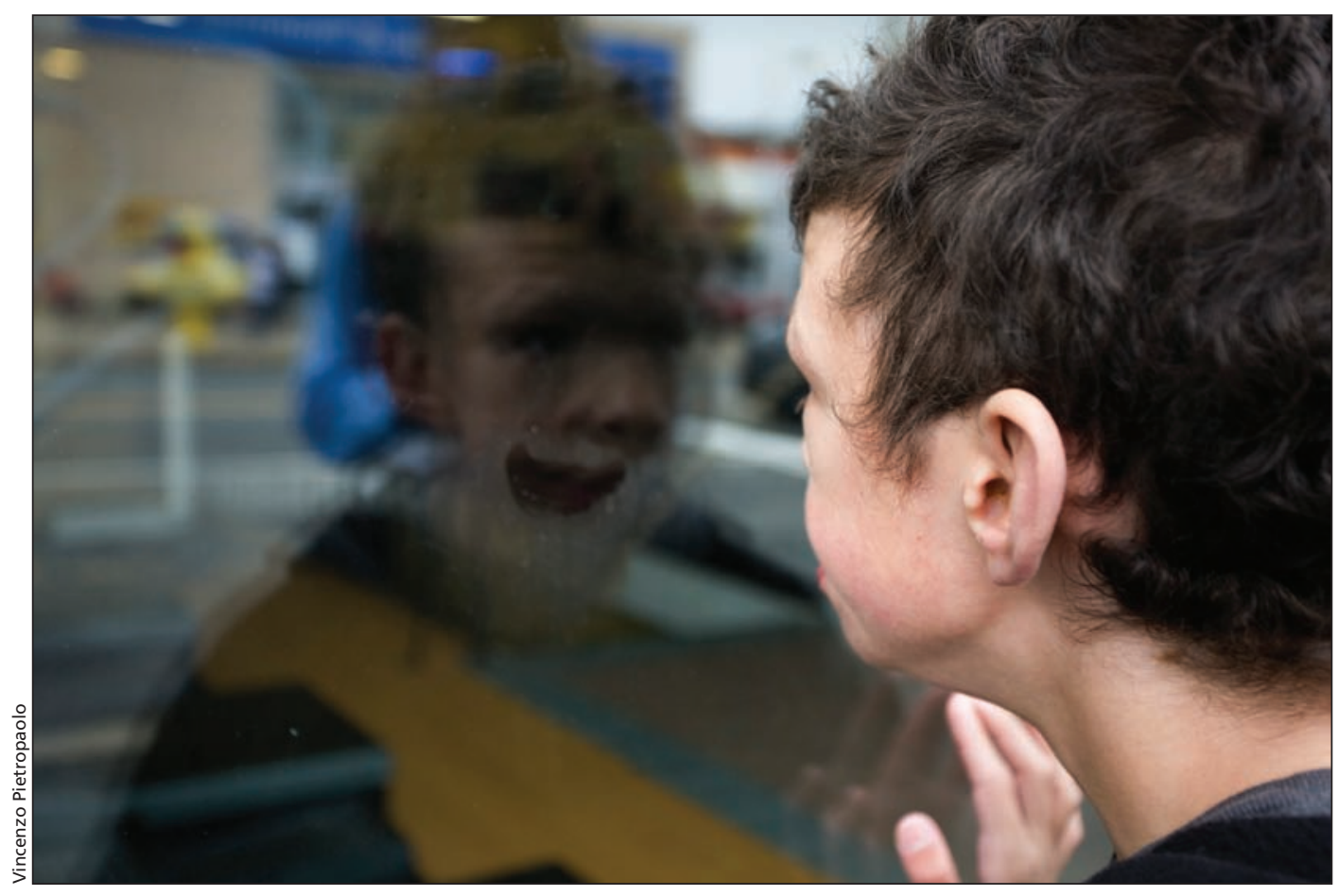

\section{Reflection}

A young boy, Luc, stops suddenly on the busy street, and stares intently inside the plate glass of a shop window. Oblivious to everything else, he is momentarily entranced by his own reflection, no different than countless children in cities and towns around the world. Except that Luc is used to being stared at in a way that other children are not. Is he different? He has pressed his mouth right against the glass plate, making a sharply delineated imprint of his tightly closed lips. The shape stands out clearly against the opaque reflection of the rest of his face. If he holds his head in the right position, the reflected face has an impish look, like the now-sad, now-happy face of a clown when he exaggerates and stretches reality into makebelieve. How different is he? This is what I am reflecting upon as I watch him. But in a moment he bounces away from the window, back into the flow of life on the street. He is soon absorbed into the crowd of pedestrians and shoppers, and just as quickly, the imprint of his lips on the plate glass fades away. 


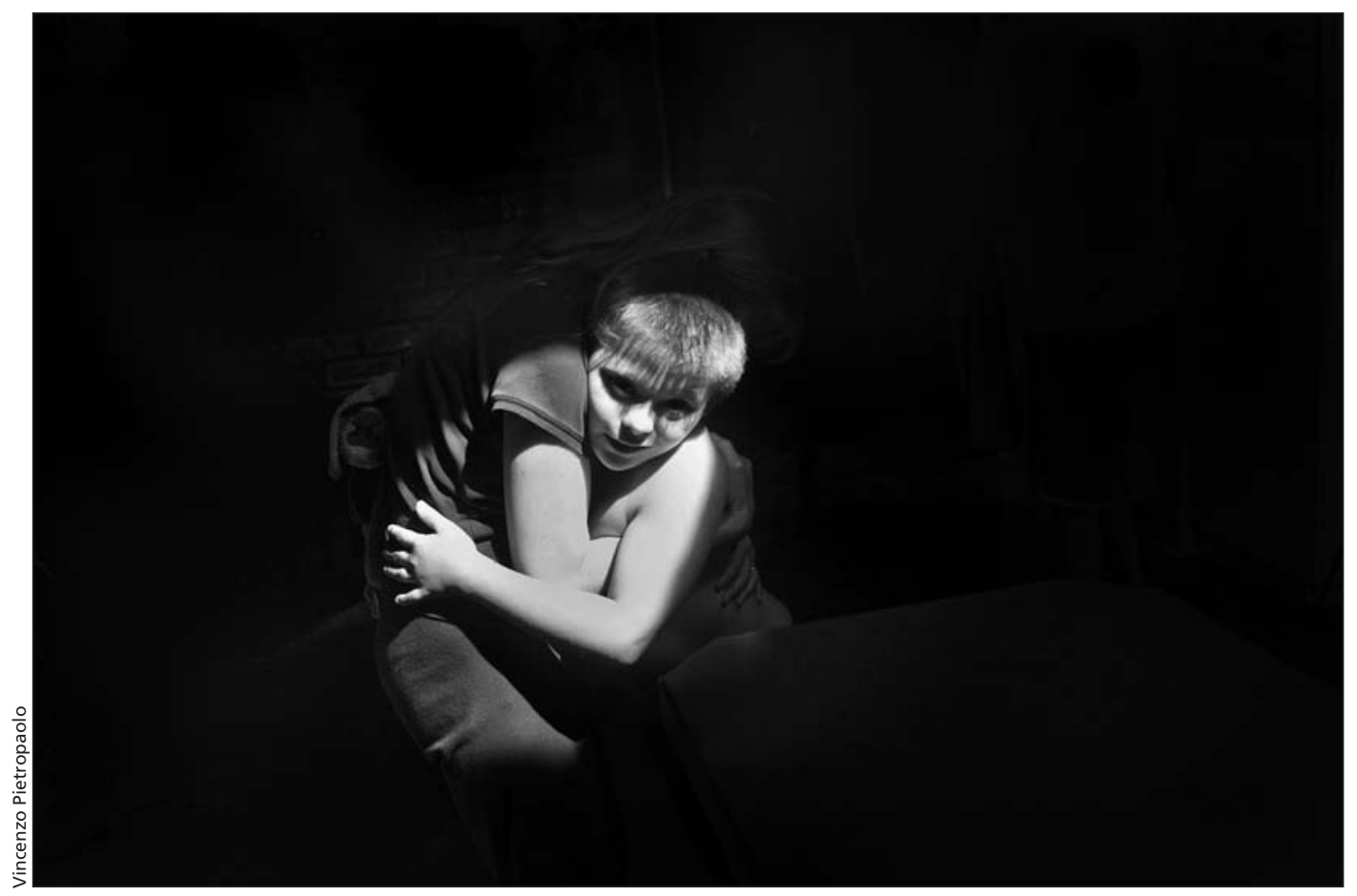

\section{Adoption}

Deb chooses her words carefully, trying not to diminish either the sense of contentment nor the intense pain that have marked her spirit, as she tells me the story of how David, her sister's birth child, came into her life. She lives with her family in a small island community off British Columbia, an idyllic place of natural beauty that belies the courage and tenacity that brought them here from the "big city" in the first place. It was their quest to find a less hectic environment in which to raise David, who was born with Down syndrome, but also a place where they could continue to find meaning and grow as a family.

It was a sudden and deliberate decision that Deb and her family made after she received a long-distance call from an official in the Ministry of Child and Family Development. The social worker was crystal clear: they would apprehend David and place him in foster care unless she came to pick him up, 300 miles away, the next day. David was barely five months old, in hospital with pneumonia, and his mother was no longer able to look after him, due to an acute crisis caused by drug addiction, which ironically, she overcame only two months later and has been drug free ever since. Deb and her husband, Hal, had already raised three children aged eleven, twelve, and sixteen, but "there was no question, absolutely no question of David coming into our family ... knowing, too, that we might have him forever." It was a huge adjustment for everyone, and at first there was much joy and laughter at the novelty of having an infant in the family, but as reality of the baby's special needs and the grind of daily life set in, things became difficult. David started to show behavioral patterns that would later be attributed to autism. Doubt set in, resentment even. Conflict developed between the family members, whose lives had now been profoundly changed by the innocent David.

There was a reverse side to the joy that David brought, for as Deb explains, "Never in my life had I been brought to my knees ... and to the ground in a way that demands that I be honest and real. Until David came I thought I could do anything, I could be an A student, an A mother, I could help the masses, and this one little boy cracked me, tore the façade completely, and for the first time in my life I said I can't do it ... He overtook everything, and brought me to a place of limitation where you get your strength. He gives me my strength, now, and my concept of faith has been shot to the ground and then transformed."

The moment that David returns home from school with his dad, he leaps into his mother's waiting arms, and a gargantuan charge of energy and joy fills the room, as mother and child seem to be protectively framed by the shafts of golden afternoon light that penetrate through the thick foliage into the kitchen window. This is the place that David has unwittingly brought her to, and while it is not the life that she had wanted, it is a life with simplicity and a clarity of purpose in which she finds ever greater meaning. Moments later David bolts out of the embrace, shakes my hand in acknowledgement, and runs to his room to play music and to dance on his bed. In his wake, he leaves something intangible in the air, waves of something that we can't quite define, as Deb and Hal and I look at each other with pure disbelief at this spurt of energy. The little tornado that just broke away from his mother's clutch has left us at a loss for words. We hear the music that he's dancing to in his bedroom, and we acknowledge as much with our eyes. "Finally," Deb says, "my life is better as a result of David." 


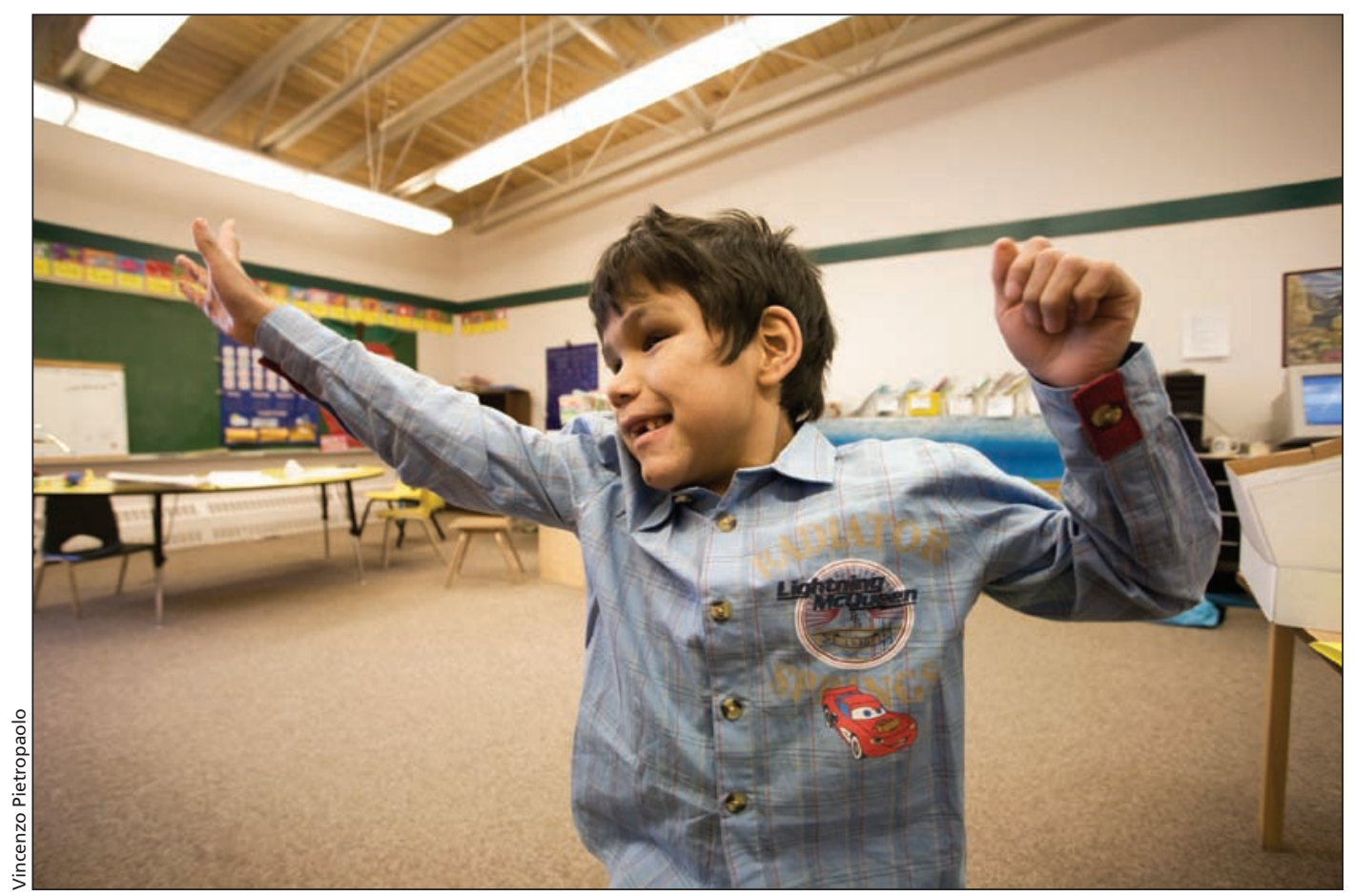

\section{Doubt}

Maurice and Mercedes are eight-year-old twins who live in the Arctic. Born with intellectual disabilities, they are also blind and mute. They live in a group home and are enrolled at the local Leo Ussak School in Rankin Inlet in Nunavut Territory. I am introduced to them in the classroom by one of their teachers. Before I can say anything, I am petrified at the improbability of the situation: I, a photographer from the far-away south, have come to make a picture of them, who are blind. What does it all mean?

I say hello to them as they approach me. "I have come to take your picture," I venture timidly. "How absurd," I think to myself. Maurice has been playing with a tambourine, holding it close to his face, and tapping the animal skin surface of the instrument. Mercedes does the same with a xylophone. I brush Maurice's hair with my hand, and, in turn, I let him brush my camera with his free hand. I had just come in from minus 15 degrees Celsius weather and the camera was extremely cold. He is startled by the smoothness and by the cold feel of metal. I can see his pleasure at this novel experience. I let him hear the click of the shutter a few times. At that, he first smiles, then puts his arm and head against my stomach to hug me. I am moved by his gesture, my throat becomes dry, and my eyes, moist. Mercedes has been taking all this in, somehow, from a distance. I don't know whether I should be making this picture at all. My doubt is real and at first I feel incapable of the task at hand. Perhaps I am crossing boundaries that I shouldn't; perhaps I am failing in my task. But moments later I instinctively lift the camera to my eye, compose a picture, and release the shutter.

I don't know what this means to Maurice and Mercedes, if anything. Through a gesture of affection, I feel that I have their permission, though I wonder: will they ever be able to see the picture? 


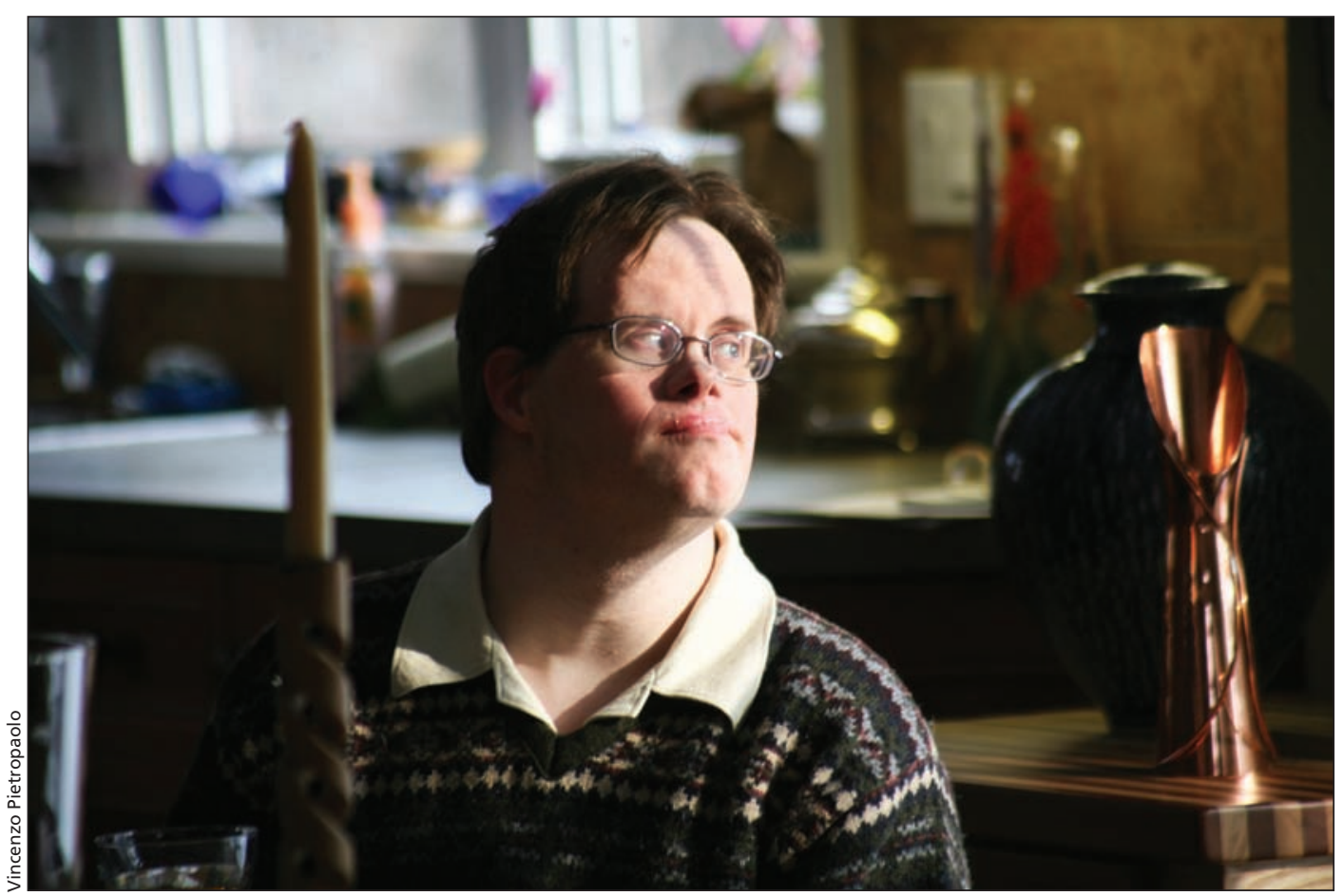

\section{A Piano Concerto}

lan and Diane are sitting at her kitchen table listening to music. It is a cold, windless day, but the late winter sun sends welcome rays of sharp light through the curtains. Outside, the snowy landscape is still, punctuated by Buddhist statuary and tall ornamental grasses that are yellowy and dried out. Some of the rays of light shine on lan's face, and he looks radiant. He sits very still, and his face has a sort of serenity about it that reminds me of the Asian faces that are carved in stone out in the garden. And like them, he has no voice to speak with. He is in a soliloquy, totally absorbed in Mozart's Piano Concerto No. 21 andante. Occasionally, he munches on a cookie, takes a sip from a glass of juice, and then quickly reassumes his listening posture. Diane has been watching him intently. She is his music teacher, and they listen to music together three times a week. By now she understands exactly what his favorite music is. The first time, she was so moved by the experience that she cried. She watched him become one with the music. On the day of my visit, the teacher said, "It's through him that I've learned to listen."

Later, I ride with lan in the minivan, sitting beside him in the back seat. He is still absorbed in the music, and re-creates every movement in his mind. As the vehicle speeds down the country road, lan "conducts" in silence, making patterns with his hands. Maybe they are random, maybe not. From my vantage point, his moving hands are silhouetted against the snow in farmers' fields, framed by the car window. It is easy to imagine some of Mozart's hauntingly beautiful notes that lan is hearing in his mind. 


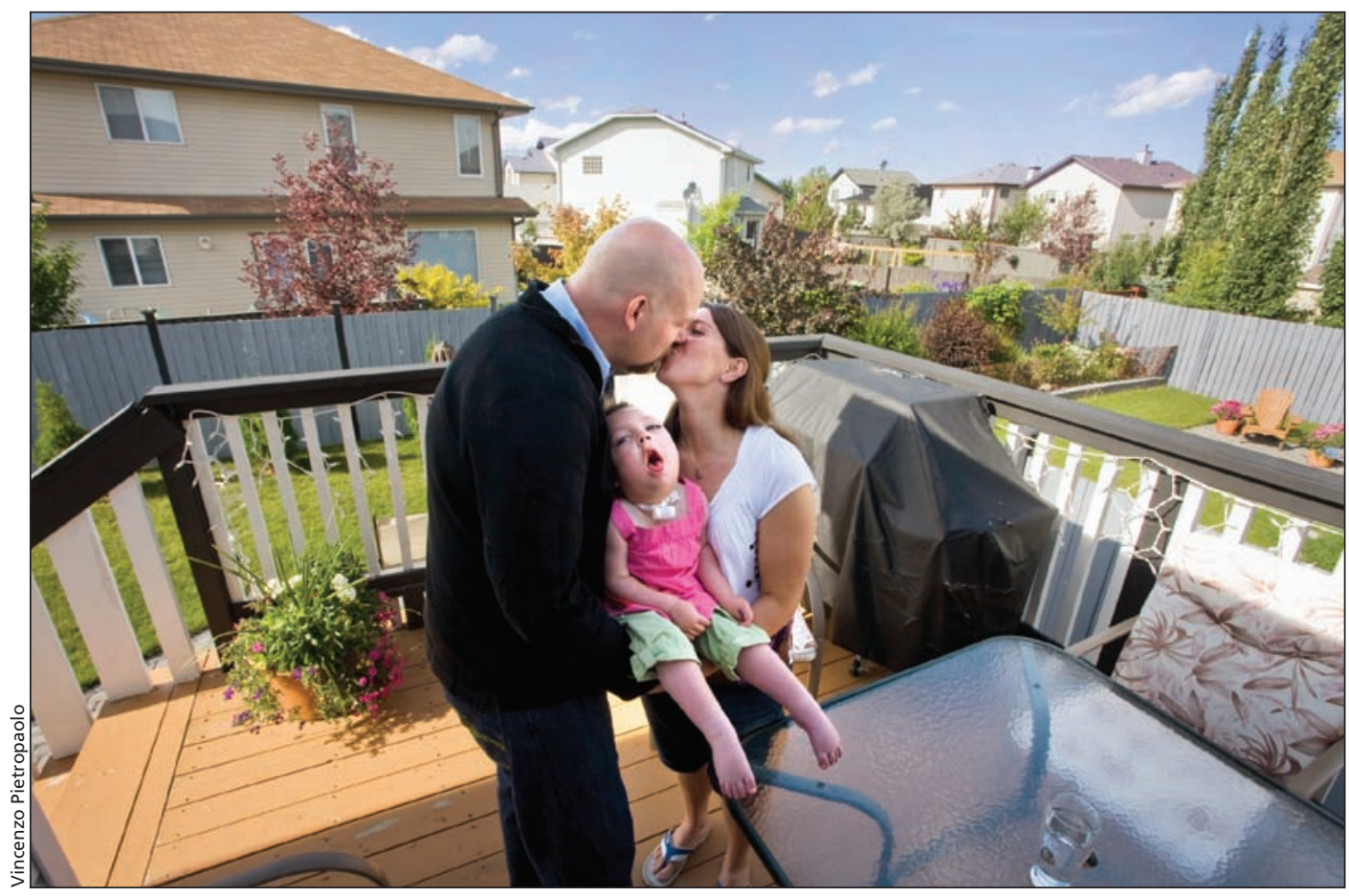

\section{Baby Won't Cry}

Driving back home from an afternoon of shopping, Christina and Chad were hit by a stolen car that was being chased by police. It was a devastating accident, more tragic than the young couple could have imagined at the time. Christina was twenty-eight years of age and pregnant with her first child. Her spleen was damaged and it ruptured. The unborn child was deprived of oxygen for possibly some thirty seconds, but her brain stem cells calcified and died. The infant Jaina was born without the basic life reflexes, "so ... she can't suck or swallow, gag or cough ... she can't take deep breaths, she has to be ventilated, and suctioned, and she eats through a tube."

At first the new parents' denial was deep, abetted also by the doctors and nurses at the hospital, but soon Christina and Chad gave up hope of becoming the parents of the child they had dreamed of. At first, they grieved for the child they thought they were going to have. But in time, the child they had did become their angel and teacher, teaching them patience, and love and acceptance, teaching them to love in ways that they had not thought possible. They learned "her language" and how to communicate with her, to focus on what she could accomplish. They learned about extensive medical care and had to become health experts to simply be parents. Through the early period of shock, Christina was in a stupor: she would never breastfeed her baby. It was a dark time in her life; only her journal gave her internal strength amid the uncontrollable crying that marked her daily existence.

Crying ... to hear her baby cry in her arms! To hear herself say "Hush, child, hush!"

Christina always thought that one day she would have a baby that would cry, like all babies do. But Jaina will not ever cry. When she hears mothers complain about their babies crying, Christina secretly feels a pang of envy; "I wish my baby would cry." 




\section{Health Care Professionals}

If you have a child that is "different," you quickly find yourself entering the obfuscating world of health care culture. You end up exposing your life to a spectrum of health professionals, most of whom you didn't even know existed, but who attach themselves to you. In David's case, an infant born with fortyseven chromosomes instead of forty-six, up to twenty-three professionals worked with him at about the same time. It began with the pediatrician, then came the heart monitor, followed by the occupational therapist, the speech therapist, the infant development program. "Wherever you want to go," says his mom Deborah, "there are teams of health experts waiting for you." Each comes with support staff connected to bureaucracies of different levels of government and regulatory bodies. You, the parent, are expected to navigate through this maze-sometimes it feels more like a jungle-always mindful to respect their territoriality, not to be antagonistic toward them even when they would deserve as much, to show gratitude instead, and stoically accept their condescending attitudes. You discover that health care is not really about heal- ing. Well, except sometimes, when you least expect it, and an angel turns up in medical garb with a gentle, understanding manner. In those moments you realize how much they could change your life, and are grateful for them.

Yes, you may be the mother or father of that "different" child, but what do you really know, madam ... sir? Leave it to us, let us peer into your life, our team has the expertise. Sooner than you realize, you have almost adopted them. Strangely, sometimes it feels as if it is you who is at their service and not they at yours. Not only do you have to teach your child everything about life, you also have to educate them about your child. But you oblige yourself to be cooperative, you keep all the appointments no matter how routine, your life becomes a litany of visits with the team. They exhaust you, your resistance to them wears you down, but you keep going. For this is what you know: you are the lifeline for your child. You do what you have to do.

You only wish that you had a support group to help you cope with the world of health care professionals. 


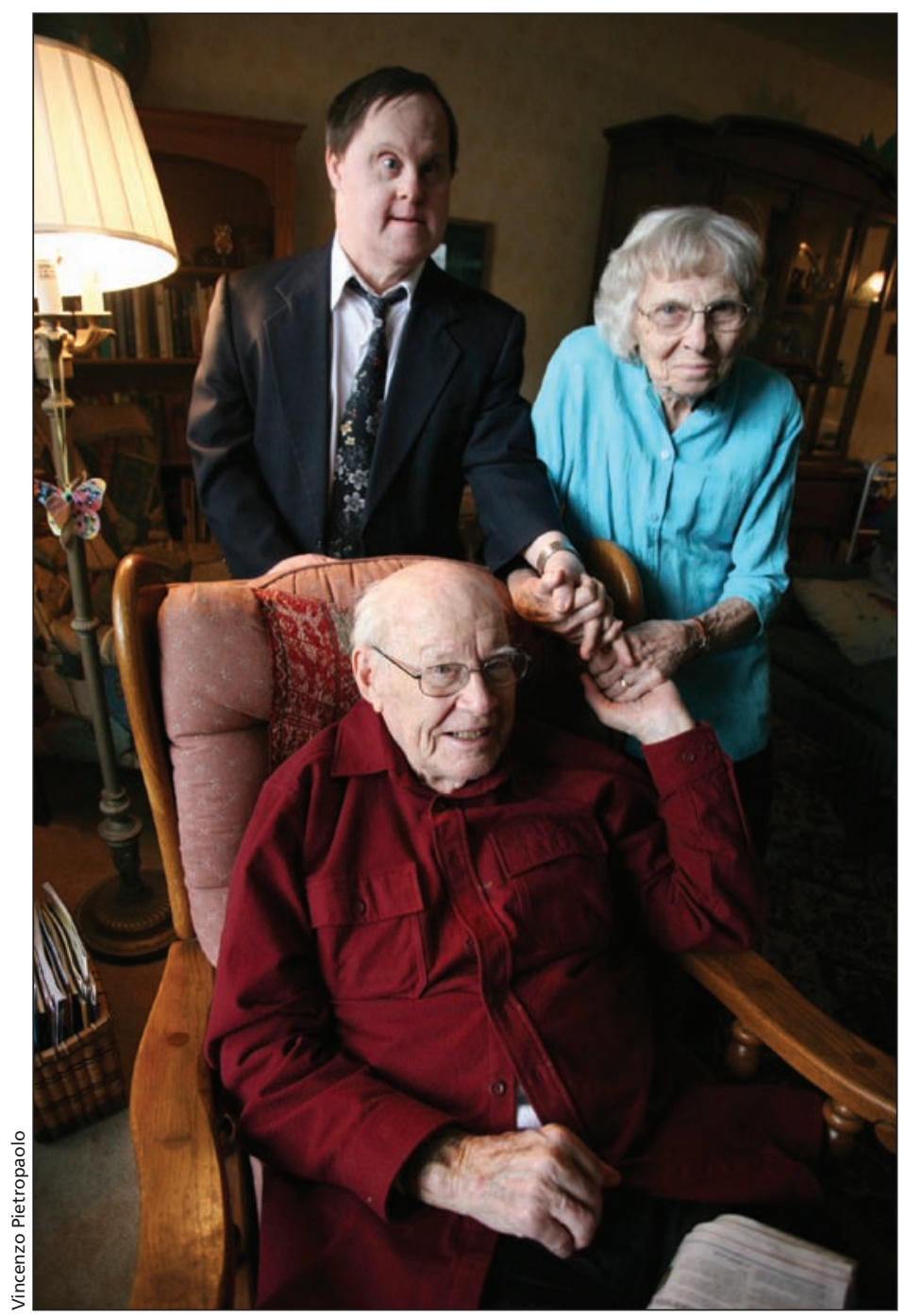

\section{Retirement Home}

The moment that I met him at the Oak Leaf Retirement Home, in Columbus, Ohio, Van moved about like a "star-inresidence," full of exuberance and brimming with passion for life. It is easy to see why he is the most popular and the most energetic resident. And at fifty-seven years of age, he is also the youngest resident of the home. Technically, he shouldn't even be there. But he had always lived with his parents, Bill and Laura, distinguished peace activists who have spent a lifetime advocating for social justice. Early on they decided that their youngest son was not going to live a life hidden in institutions or secluded in group homes just because of that extra chromosome that he was born with.

His birth propelled the parents even more deeply into social justice struggles, and his mother's teaching and father's work as a minister of the United Church took them to places like Japan, the Philippines, England, and across the United States. Soon they were at the forefront of the disabilities movement, long before the recent seismic shifts in attitudes. They organized seminars, study groups and gatherings of all kinds, including a conference to mark the International Year of Disabled Persons, where "we tried to get, as much as we could, a balance between those who had visible signs of disabilities and those who didn't ... One day we went and took the people in wheelchairs down by the river and some of the people in wheelchairs went into the boats, and some went horseback riding. At about the end of the evening there was no sense of ability, disability, and language. It was just that. We're one. We're all the same." Van was always at their side, at the center of it all, and if the parent's mission was a "mission of inclusion," the son was its enduring symbol. 